\title{
Frequency recommendation for long term evolution network implementation using simple multi attribute rating technique
}

\author{
Putri Angelia, Rendy Munadi, Nachwan Mufti Adriansyah \\ Department of Electrical Engineering, Faculty of Electrical Engineering, Telkom University, Bandung, West Java, Indonesia
}

\begin{tabular}{|c|c|}
\hline Article Info & ABSTRACT \\
\hline Article history: & \multirow{11}{*}{$\begin{array}{l}\text { The increasing demand for telecommunication services causes data traffic } \\
\text { density. Therefore, in this research, the long-term evolution (LTE) network } \\
\text { expansion was carried out using a choice of frequency bands of } 700 \mathrm{MHz} \text {, } \\
2100 \mathrm{MHz} \text {, and } 2300 \mathrm{MHz} \text {. The analysis was carried out from the technical } \\
\text { and economic aspects. Frequency band recommendations were obtained using } \\
\text { the simple multi-attribute rating technique (SMART) method. This research } \\
\text { was conducted using a case study of Semarang City. Based on the simulation } \\
\text { results, the average of reference signal receive power (RSRP) values for } \\
\text { frequency } 700 \mathrm{MHz} \text { and } 2300 \mathrm{MHz} \text { in in the very good range, while the } \\
\text { frequency of } 2100 \mathrm{MHz} \text { is in the good range. The signal to interference noise } \\
\text { ratio (SINR) values for the three frequencies are in the normal category and } \\
\text { the throughput values are in the very good category. The techno-economic } \\
\text { calculations of the three frequencies, namely the value of internal rate of return } \\
\text { (IRR), net present value (NPV), and payback period are included in the } \\
\text { business category that is feasible to do. Based on the ranking results, the } 700 \\
\text { MHz frequency is the most superior, both in terms of technical and economic } \\
\text { aspects. }\end{array}$} \\
\hline Received Jul 31, 2021 & \\
\hline Revised Oct 12, 2021 & \\
\hline Accepted Dec 29, 2021 & \\
\hline Keywords: & \\
\hline Capacity planning & \\
\hline Coverage planning & \\
\hline LTE & \\
\hline $\begin{array}{l}\text { Simple multi attribute rating } \\
\text { technique }\end{array}$ & \\
\hline & \\
\hline & \\
\hline
\end{tabular}

This is an open access article under the CC BY-SA license.

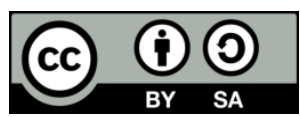

\section{Corresponding Author:}

Putri Angelia

Department of Electrical Engineering, Faculty of Electrical Engineering, Telkom University Jl. Telekomunikasi No. 1, Terusan Buahbatu-Bojongsoang, Sukapura, Bandung, West Java, Indonesia Email: ptriangelia@student.telkomuniversity.ac.id

\section{INTRODUCTION}

The increasing demand for services that require high bandwidth and the need for data traffic services on a massive scale makes the network capacity full. Based on data or information from cellular operators, the current condition has occurred in a situation of cellular network density or called congestion so that throughput on the customer side has decreased. According to data from Cisco, by 2023 the population in global will have mobile connectivity over $70 \%$. The mobile subscribers will be increase from $66 \%$ of the population in 2018 to $71 \%$ of the population in 2023. By 2023, 4G networks will increase by $4 \%$ from $42 \%$ in 2018 to $46 \%$ of total cellular connections. Mobile 4G connections on a global scale from 3.7 billion in 2018 will be increase to 6.0 billion in 2023 [1]-[7]. An example, what happened in Indonesia, the government assessed that there had been network congestion in several big cities in Indonesia such as Medan, Semarang, Yogyakarta, Surabaya, Denpasar, Pontianak, Makassar, Jakarta, Bogor, Depok, Tangerang, and Bekasi, which resulted in a decrease in network quality. These problems make telecommunications networks facing new challenges but also have new opportunities for development. One way to solve this problem is to expand the long-term evolution (LTE) network. However, to expand the network, additional frequencies are needed, there are several frequency options that can be used for the implementation of LTE networks, such as $700 \mathrm{MHz}, 2100 \mathrm{MHz}$, and 2300 $\mathrm{MHz}$ [8], [9]. Network expansion needs to be reviewed both from a technical and economic perspective so that 
the quality of service provided to customers is good and from a business perspective it can generate profits so that it can be a solution to these problems.

\section{METHOD}

This research was conducted in several stages, the initial stage is calculating capacity planning and coverage planning to determine the number of sites to be simulated to find the value of technical parameters, namely reference signal receive power (RSRP), signal to interference noise ratio (SINR), and throughput. The next stage is to conduct an economic analysis with techno-economic calculations to find the value of internal rate of return (IRR), net present value (NPV), and payback period to find out whether the business is feasible or not. The decision-making method to recommend the best frequency band is done by using a simple multiattribute rating technique (SMART).

\subsection{Capacity planning}

Capacity planning serves to determine the number of sites based on customer needs. In capacity planning, predictions of the population for the next few years are carried out using as (1) [10]. Where Po is the current population, $G F$ is the growth factor, and $\mathrm{n}$ is the number of estimated years. In addition, it also predicts the number of LTE subscribers by multiplying the number of productive ages with the market share value and LTE penetration from the provider used. Capacity planning also considers the throughput value for each service and cell capacity to determine the number of sites needed.

$$
P n=P o(1+G F)^{n}
$$

\subsection{Coverage planning}

Coverage planning serves to determine the number of sites needed based on the coverage area in the case study. In coverage planning, maximum allowed pathloss (MAPL) is calculated using as (2). Where EIRP is effective isotropic radiated power $(\mathrm{dBm})$ which can be calculated using as (3), RS is receiver sensitivity $(\mathrm{dBm})$ which can be calculated using as (4), IM is interference margin $(\mathrm{dB}), L_{R X}$ is reception losses $(\mathrm{dB}), G_{R X}$ is reception gain $(\mathrm{dB}), F M$ is fading margin $(\mathrm{dB}), P_{T X}$ is transmission power $(\mathrm{dBm}), G_{T X}$ is antenna gain $(\mathrm{dB})$, and $L_{T X}$ is transmission losses (dB). The coverage planning uses okumura hatta for frequency $700 \mathrm{MHz}$ and Cost-231 propagation models for $2100 \mathrm{MHz}$ and $2300 \mathrm{MHz}$ [11]-[14].

$$
\begin{aligned}
& M A P L=E I R P-R S-I M-L_{R X}+G_{R X}-F M \\
& E I R P=P_{T X}+G_{T X}-L_{T X}
\end{aligned}
$$

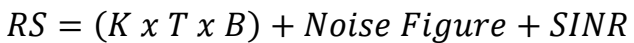

\subsection{Signal to interference noise ratio}

Signal to interference noise ratio (SINR) is the ratio of the main signal strength to the resulting interference signal (noise) [15], [16]. The SINR parameter indicates the minimum power level at which the user can still make a call. If the SINR value is below $0 \mathrm{~dB}$ it means the received signal strength is bad. Table 1 shown the range of SINR quality values [17].

\begin{tabular}{cl} 
Table 1. SINR quality value range \\
\hline SINR values (dB) & Quality \\
\hline 16 to 30 & Good \\
1 to 15 & Normal \\
-10 to 0 & Poor
\end{tabular}

\subsection{Throughput}

Throughput is a parameter value that shows the speed of service received by the user [18]. The throughput parameter is measured in a certain time unit with the network conditions used to transfer data. Throughput quality can be said to be good if it has a value above $700 \mathrm{kbps}$ and poor quality if it is below 338 kbps. Table 2 shown the range of throughput quality values. 
Table 2. Throughput quality value range

\begin{tabular}{ll}
\hline Throughput (kbps) & Quality \\
\hline$>1200$ & Very Good \\
$700-1200$ & Good \\
$338-700$ & Fair \\
$0-338$ & Poor \\
\hline
\end{tabular}

\subsection{Reference signal receive power}

Reference signal received power (RSRP) is an indicator that shows the signal strength of the eNodeB received by user equipment (UE) [18]. The RSRP value is used to show the quality of network coverage in an area, the greater the RSRP value, the better the quality of the signal emitted by the transmitter. Table 3 shown the range of RSRP quality values [17].

Table 3. RSRP quality value range

\begin{tabular}{ll}
\hline RSRP values $(\mathrm{dBm})$ & \multicolumn{1}{c}{ Quality } \\
\hline RSRP $\geq-70$ & Excellent \\
$-71>$ RSRP $>-81$ & Good \\
$-81>$ RSRP $>-91$ & Normal \\
$-91>$ RSRP $>-101$ & Poor \\
RSRP $<-101$ & Very Poor \\
\hline
\end{tabular}

\subsection{Internal rate of return}

Internal rate of return (IRR) is a method used to calculate the level of investment. The IRR calculation can be used as a reference to see whether the business to be run will be more profitable or not. IRR also an indicator of the level of efficiency of an investment that serves to clearly determine the rate of return of a business. IRR calculation using as (5). where $C F_{t}$ is the cash flow per year in period $\mathrm{t}, C_{0}$ is the initial investment in year zero, $\mathrm{n}$ is the number of years, and $\mathrm{t}$ is year $\mathrm{t}$.

$$
C_{0}=\sum_{t=1}^{n} \frac{C F_{t}}{(1+I R R)^{t}}
$$

\subsection{Net present value}

Net present value (NPV) is the difference value between expenses and income in a certain period. In general, the NPV calculation is used to project the potential profit that will be generated on an investment or business that will be run. If NPV $>0$, then the project is feasible, NPV $=0$, it means the company has neither profit nor loss, NPV $<0$, then the company is not feasible [19]. NPV calculation can be calculated using as (6). Where $C F_{t}$ is the cash flow per year in period $\mathrm{t}, \mathrm{i}$ is the value of interest rate, the initial investment in year 0 is $C_{0}, \mathrm{n}$ is the total of years, and $\mathrm{t}$ is year $\mathrm{t}$.

$$
N P V=\sum_{t=1}^{n} \frac{C F_{t}}{(1+i)^{t}}-C_{0}
$$

\subsection{Payback period}

Payback period (PBP) is a period that shows how long the capital issued can be returned. The faster the payback period is generated, the more attractive the business is to run. Payback periods that are too long usually make the business is not feasible to run. PBP can be formulated in as (7). Where PBP is the payback period, $C_{0}$ is the required investment cost, and $C$ is the annual cash flow.

$$
P B P=\frac{C_{0}}{C}
$$

\subsection{Simple multi attribute rating technique}

Recommendation decisions are made by comparing each research result from both a technical and economic perspective. The results of the comparison will be ranked for the three frequencies, there are 700 MHz, $2100 \mathrm{MHz}$, and $2300 \mathrm{MHz}$. The weighting and decision-making methods are carried out using the simple multi-attribute rating technique (SMART) [20]-[24]. The steps for the SMART method are:

- Determine eligibility parameters.

- Give weight to each parameter using a priority scale from 1-100 (lowest priority to highest priority).

- Calculate the normalization of each weighted parameter using as (8): 


$$
W_{j}=\frac{w_{j}}{\sum_{j=1}^{m} w_{j}}
$$

where $W_{j}$ is the normalized weight of the criteria to $\mathrm{j}, w_{j}$ is the weight value of the criteria to $\mathrm{j}, \mathrm{m}$ is the number of criteria, and $w_{m}$ is the weight of the criteria to $\mathrm{m}$.

- Provide parameter values for each data, parameter values for each of these data can be in the form of quantitative or qualitative.

- Specifies the utility value for each parameter. There are 2 categories of utility values, the first category is "the greater value is more desirable" which is calculated as (9) and the second category is "smaller value is more desirable" with (10):

$$
\begin{aligned}
& u_{i}\left(a_{i}\right)=\frac{C_{\max }-C_{\text {out }}}{C_{\max }-C_{\min }} \times 100 \% \\
& u_{i}\left(a_{i}\right)=\frac{C_{\text {out }}-C_{\min }}{C_{\max }-C_{\min }} \times 100 \%
\end{aligned}
$$

where $u_{i}\left(a_{i}\right)$ is the utility value for the i parameter, $C_{\max }$ is the maximum parameter value, $C_{\min }$ is the minimum parameter value, and $C_{\text {out }}$ is the i parameter.

- Determine the final value, by multiplying the utility value result with the weight normalization result and then adding up the values of all parameters.

\section{RESULTS AND DISCUSSION}

\subsection{Technical analysis}

This research used a case study of Semarang City which has a population of 1,653,524 people based on data from statistics Indonesia with an area of $373.3 \mathrm{~km}^{2}$ [25] which is divided into three types of areas, namely urban, suburban, and rural. The distribution of the population in urban areas is around $51.10 \%$, suburban areas are around $38.08 \%$, and rural areas are around $10.82 \%$ of the total population. In this research, the bandwidth used is $15 \mathrm{MHz}$ with the assumption that the provider used is Telkomsel which has a market share value of $59.2 \%$ and LTE penetration of $82.36 \%$. The site height in the urban area is $30 \mathrm{~m}$, the suburban area is $50 \mathrm{~m}$, and the rural area is $80 \mathrm{~m}$. After predicting the number of LTE subscribers in the next five years, it is possible to predict the number of sites required based on customer needs. The number of sites required based on the calculation of capacity planning is more than the calculation of coverage planning. The $2300 \mathrm{MHz}$ frequency requires the greatest number of sites compared to other frequencies because the service coverage that can be found by the $2300 \mathrm{MHz}$ frequency is smaller. After knowing the number of sites, a simulation is carried out to determine the quality of service. Figure 1(a) shown the site's prediction based on capacity planning. Figure 1(b) shown the site's prediction based on coverage planning.

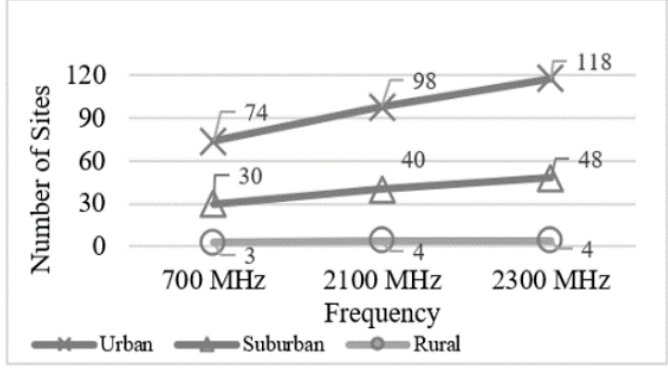

(a)

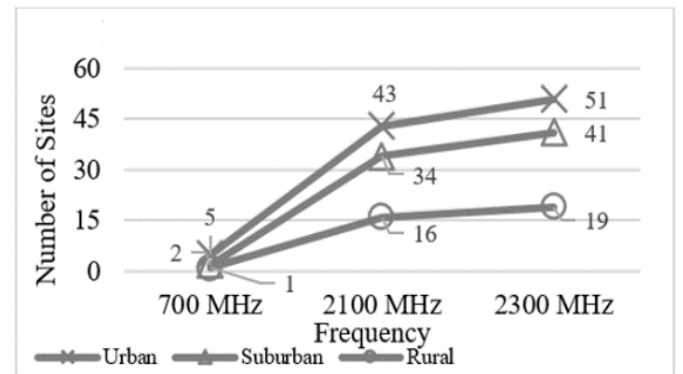

(b)

Figure 1. Number of sites by (a) capacity planning and (b) coverage planning

Table 4 shown the RSRP, SINR, and throughput values for the three frequencies. Figure 2 shown the simulation results of the $700 \mathrm{MHz}$ frequency. Figure 2(a) shown the RSRP value. Figure 2(b) shown the SINR value. Figure 2(c) shown the throughput value. The results of the RSRP frequency of $700 \mathrm{MHz}$ are in the very good category, the SINR value is included in the normal category, and the throughput value is in the very good category based on the range value table. 
Table 4. Technical parameters value

\begin{tabular}{cccc}
\hline Parameter & RSRP $(\mathrm{dBm})$ & SINR $(\mathrm{dB})$ & Throughput $(\mathrm{kbps})$ \\
\hline $700 \mathrm{MHz}$ & -53.05 & 6.58 & $18,656.81$ \\
$2100 \mathrm{MHz}$ & -72.28 & 4.53 & $10,503.56$ \\
$2300 \mathrm{MHz}$ & -68.08 & 4.43 & $10,428.21$ \\
\hline
\end{tabular}

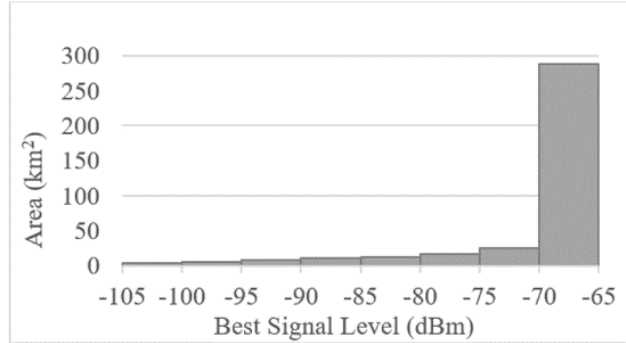

(a)

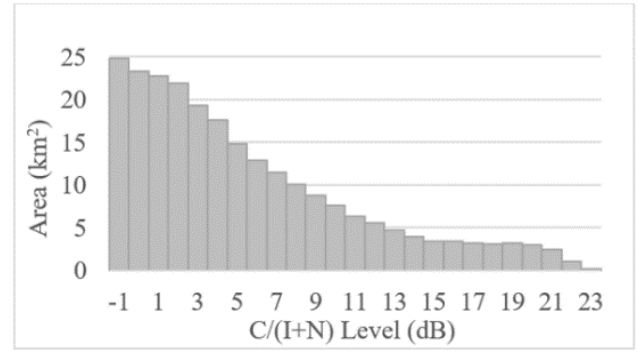

(b)

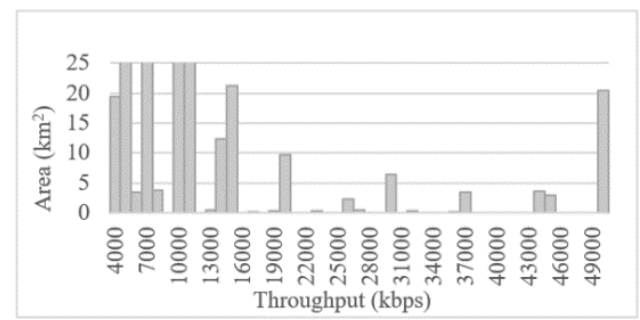

(c)

Figure 2. $700 \mathrm{MHz}$ simulation, (a) RSRP, (b) SINR, and (c) throughput

Figure 3 shown the simulation results of the $2100 \mathrm{MHz}$ frequency. Figure 3(a) shown the RSRP value. Figure 3(b) shown the SINR value. Figure 3(c) shown the throughput value. The results of the RSRP frequency of $2100 \mathrm{MHz}$ are in a good category, the results are lower than the frequencies of $700 \mathrm{MHz}$ and $2300 \mathrm{MHz}$ The SINR value is included in the normal category and the throughput value is included in the very good category based on the range value table.

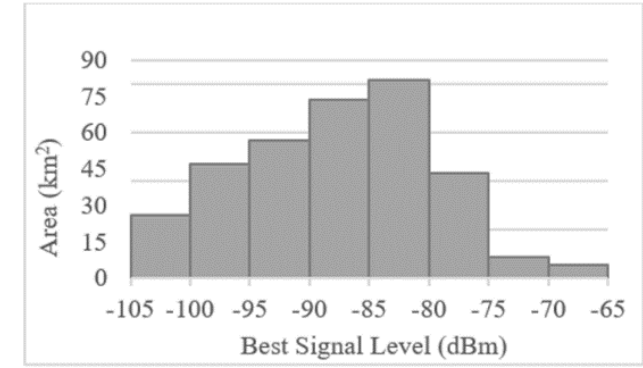

(a)

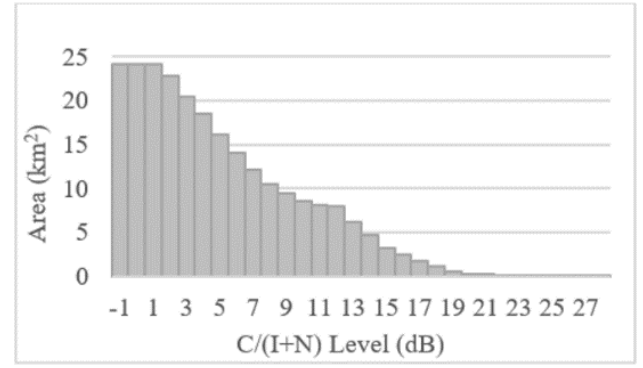

(b)

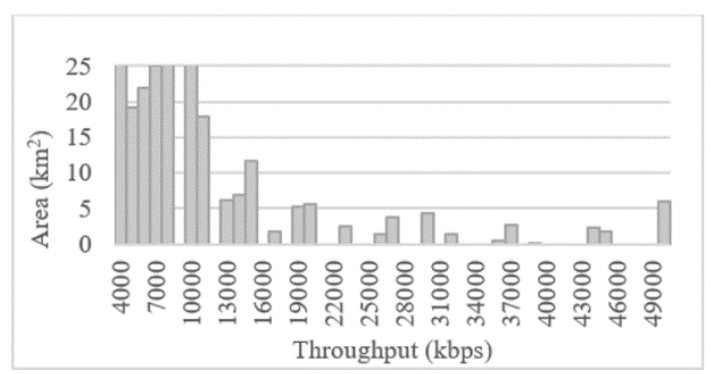

(c)

Figure 3. $2100 \mathrm{MHz}$ simulation, (a) RSRP, (b) SINR, and (c) throughput 
Figure 4 shown the simulation results of the $2300 \mathrm{MHz}$ frequency. Figure 4(a) shown the RSRP value. Figure 4(b) shown the SINR value. Figure 4(c) shown the throughput value. The results of the RSRP frequency of $2300 \mathrm{MHz}$ are included in the very good category. The SINR value is included in the normal category, which means that the noise is not too disturbing, and the throughput value is included in the very good category based on the range value table.

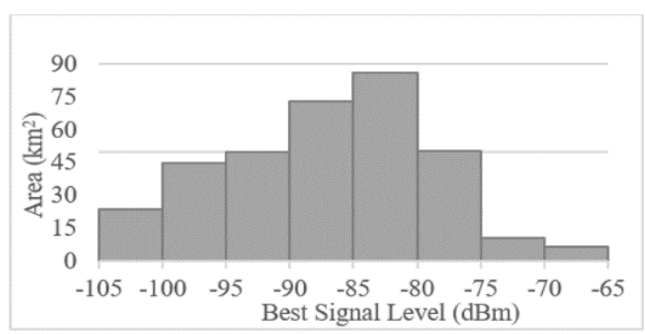

(a)

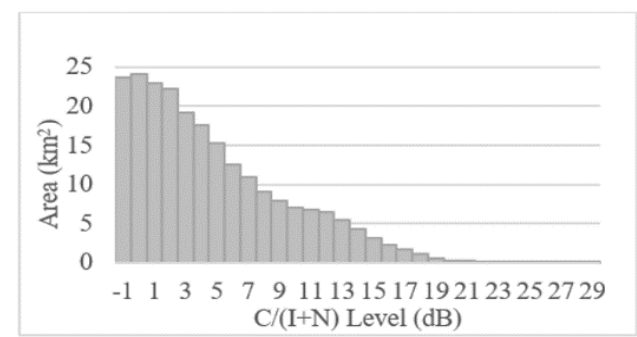

(b)

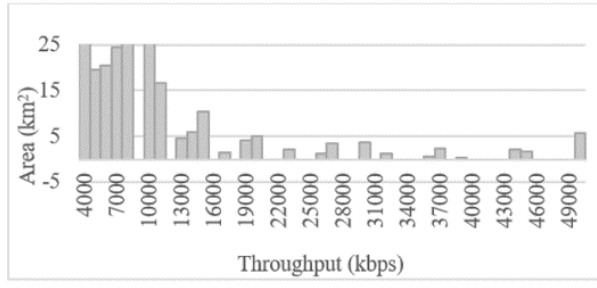

(c)

Figure 4. $2300 \mathrm{MHz}$ simulation, (a) RSRP, (b) SINR, and (c) throughput

\subsection{Economic analysis}

In the economic calculation, it is necessary to predict the capital expenditures (CAPEX) and operational expenditures (OPEX) costs of each frequency for the implementation of the LTE network. The CAPEX value includes the cost of eNodeB, license, pre-installation, and supporting equipment. The OPEX value includes operational and maintenance costs, tower rental, employee costs, and telecommunication usage fees. Figure 5(a) shown the graph of the CAPEX value. Figure 5(b) shown the graph of OPEX value.

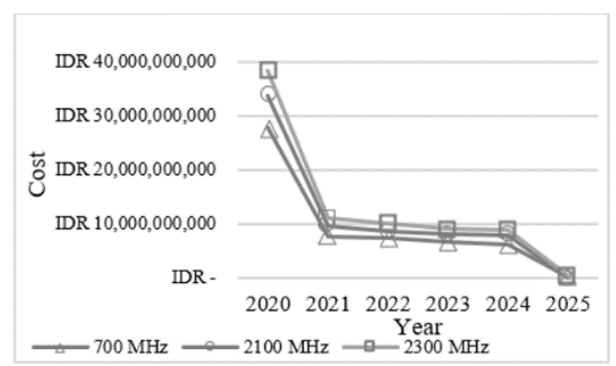

(a)

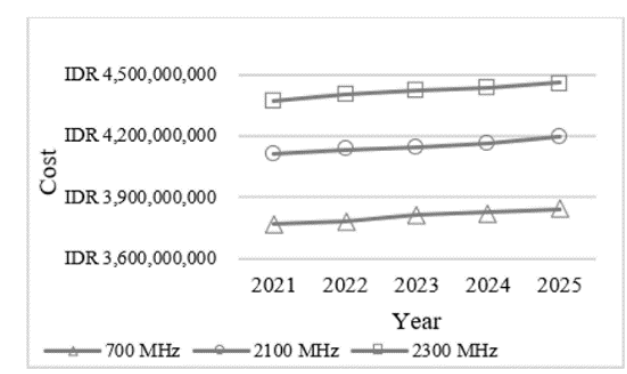

(b)

Figure 5. Economic values (a) CAPEX and (b) OPEX

The frequency of $2300 \mathrm{MHz}$ requires the highest cost from both CAPEX and OPEX. The $700 \mathrm{MHz}$ frequency requires the lowest cost compared to the other two frequencies. Based on the projected CAPEX and OPEX values in the next five years, it can be predicted that the business feasibility for each frequency can be seen from the IRR, NPV, and PBP values contained in the Table 5.

Table 5. Economic parameters value

\begin{tabular}{ccccc}
\hline Parameter & IRR & & NPV & PBP \\
\hline $700 \mathrm{MHz}$ & $49.37 \%$ & IDR & $38,911,752,567$ & $2^{\text {nd }}$ year \\
$2100 \mathrm{MHz}$ & $30.23 \%$ & IDR & $23,956,362,641$ & $3^{\text {rd }}$ year \\
$2300 \mathrm{MHz}$ & $18.19 \%$ & IDR & $11,956,978,575$ & $4^{\text {th }}$ year \\
\hline
\end{tabular}




\subsection{Technical analysis}

The results obtained from the research will be compared by giving a weighting for each frequency. The weighting method is carried out using SMART. The weighting for each parameter is assumed to be equally important so that the weight given is 100 for each parameter. The result of the normalized value of the weighting using as (8) is 0.17 . Table 6 shown the utility value of each parameter using as (9) and as (10) and the final value of each parameter.

Table 6. Utility value and final value of each parameter based on smart method

\begin{tabular}{|c|c|c|c|c|c|c|c|}
\hline \multirow{2}{*}{ Parameter } & \multirow{2}{*}{ Category } & \multicolumn{3}{|c|}{ Utility values } & \multicolumn{3}{|c|}{ Final value } \\
\hline & & $700 \mathrm{MHz}$ & $2100 \mathrm{MHz}$ & $2300 \mathrm{MHz}$ & $700 \mathrm{MHz}$ & $2100 \mathrm{MHz}$ & $2300 \mathrm{MHz}$ \\
\hline RSRP & First category & 1.00 & 0.00 & 0.22 & 0.167 & 0.000 & 0.036 \\
\hline SINR & First category & 1.00 & 0.05 & 0.00 & 0.167 & 0.008 & 0.000 \\
\hline Throughput & First category & 1.00 & 0.01 & 0.00 & 0.167 & 0.002 & 0.000 \\
\hline NPV & First category & 1.00 & 0.45 & 0.00 & 0.167 & 0.074 & 0.000 \\
\hline IRR & First category & 1.00 & 0.39 & 0.00 & 0.167 & 0.064 & 0.000 \\
\hline PBP & Second category & 1.00 & 0.50 & 0.00 & 0.167 & 0.083 & 0.000 \\
\hline \multicolumn{5}{|c|}{ Total Final Value } & 1.000 & 0.231 & 0.036 \\
\hline
\end{tabular}

\section{CONCLUSION}

In conclusion, network congestion can be overcome by expanding or adding LTE networks using additional frequencies. The implementation of the LTE network using the frequencies of $700 \mathrm{MHz}, 2100 \mathrm{MHz}$, and $2300 \mathrm{MHz}$ has different potential feasibility, both from technical and economic perspectives. Based on the final value obtained from the calculation using the SMART method, the $700 \mathrm{MHz}$ frequency has the superior potential both in terms of technical and economic feasibility. The implementation of an LTE network using a frequency of $700 \mathrm{MHz}$ can provide benefits for operators because it has the potential to have greater benefits from economic aspects and benefits for customers because they get better service and signal quality compared to the other two frequencies. So, with the SMART method as a support for decision making, it can be recommended that the $700 \mathrm{MHz}$ frequency band is the most superior for LTE network implementation.

\section{REFERENCES}

[1] T. H. Dao, "On optimal designs of transparent WDM networks with $1+1$ protection leveraged by all-optical XOR network coding schemes," Optical Fiber Technology, vol. 40, pp. 93-100, 2018, doi: 10.1016/j.yofte.2017.11.009.

[2] D. T. Hai, "On routing, spectrum and network coding assignment problem for transparent flex-grid optical networks with dedicated protection," Computer Communications, vol. 147, pp. 198-208, 2019, doi: 10.1016/j.comcom.2019.08.005.

[3] D. T. Hai, "On solving the $1+1$ routing, wavelength and network coding assignment problem with a bi-objective integer linear programming model," Telecommunication Systems, vol. 71, no. 2, pp. 155-165, 2019, doi: 10.1007/s11235-018-0474-9.

[4] D. T. Hai, "A Bi-objective integer linear programming model for the routing and network coding assignment problem in WDM optical networks with dedicated protection," Computer Communications, vol. 133, pp. 51-58, 2019, doi: 10.1016/j.comcom.2018.08.006.

[5] Cisco, "Cisco Annual Internet Report (2018-2023)," White paper Cisco public, 2018. https://www.cisco.com/c/en/us/solutions/collateral/executive-perspectives/annual-internet-report/white-paper-c11-741490.pdf.

[6] D. T. Hai, M. Morvan, and P. Gravey, "Combining heuristic and exact approaches for solving the routing and spectrum assignment problem," IET Optoelectronics, vol. 12, no. 2, pp. 65-72, 2018, doi: 10.1049/iet-opt.2017.0013.

[7] N. A. Hassan and R. Hijazi, "Future Trends," Impedance Source Power Electronic Converters, pp. 390-400, 2016, doi: 10.1002/9781119037088.ch20.

[8] V. Sridhar and R. Prasad, "Analysis of spectrum pricing for commercial mobile services: A cross country study," Telecommunications Policy, vol. 45, no. 9, p. 102221, 2021, doi: 10.1016/j.telpol.2021.102221.

[9] Indonesian Ministry of Communication and Informatics, "Physical condition of cellular mobile telecommunication network 'congestion' in non-rural areas," Indonesian Ministry of Communication and Informatics, 2017. https://www.kominfo.go.id/content/detail/9660/siaran-pers-no-60hmkominfo052017-tentang-kondisi-fisik-congestion-jaringantelekomunikasi-bergerak-seluler-pada-wilayah-non-rural/0/siaran_pers.

[10] R. Nlend and E. Tonye, "Planning and simulation of LTE radio network: case of the city of Yaoundé," IOSR Journal of Electronics and Communication Engineering (IOSR-JECE), vol. 14, no. 2, pp. 19-29, 2019, doi: 10.9790/2834-1402011929.

[11] N. M. D. Ksamawati, D. Gunawan, and M. I. Nashiruddin, "Pushing the LTE Capability towards 5G: The Analysis of Licensed Assisted Access (LAA) Implementation for High-Density Area in Indonesia," ICITEE 2020 - Proceedings of the 12th International Conference on Information Technology and Electrical Engineering, pp. 15-20, 2020, doi: 10.1109/ICITEE49829.2020.9271746.

[12] A. Jha and D. Saha, "Why is $700 \mathrm{MHz}$ band a good proposition for provisioning pan-India 4G LTE services?: A comparative techno-economic evaluation study," 2017 9th International Conference on Communication Systems and Networks, COMSNETS 2017, pp. 229-236, 2017, doi: 10.1109/COMSNETS.2017.7945381.

[13] A. Jha and D. Saha, "Techno-commercial feasibility analysis of 4G mobile services in India," IIMB Management Review, vol. 31, no. 2, pp. 182-199, 2019, doi: 10.1016/j.iimb.2019.03.007.

[14] Q. Yuan, Q. Qian, Y. Mo, and H. Chen, "Research on mixed planning method of 5G and LTE," Proceedings - 3rd International Conference on Information and Computer Technologies, ICICT 2020, pp. 489-493, 2020, doi: 10.1109/ICICT50521.2020.00084.

[15] S. Banerjee and V. V. Dwivedi, "Effect of signal to interference ratio on adaptive beamforming techniques," Journal of King Saud University - Engineering Sciences, vol. 30, no. 4, pp. 313-319, 2018, doi: 10.1016/j.jksues.2016.08.002. 
[16] J. A. Sheikh, M. ul Amin, S. A. Parah, and G. M. Bhat, "Impact of antenna and beam-selection-based sectored relay planning for performance evaluation of 4G LTE-A tri-sectored cell," Digital Communications and Networks, vol. 5, no. 2, pp. 121-130, 2019, doi: 10.1016/j.dcan.2017.08.006.

[17] D. Rianti, A. Hikmaturokhman, and D. Rachmawaty, "Techno-Economic 5G New Radio Planning Using 26 GHz Frequency at Pulogadung Industrial Area," 2020 3rd International Seminar on Research of Information Technology and Intelligent Systems, ISRITI 2020, pp. 272-277, 2020, doi: 10.1109/ISRITI51436.2020.9315455.

[18] D. Micheli et al., "MIMO $4 \times 4$ vs. MIMO $2 \times 2$ performance assessment of a real life LTE base station in a reverberation chamber," AEU - International Journal of Electronics and Communications, vol. 129, p. 153500, 2021, doi: 10.1016/j.aeue.2020.153500.

[19] N. Ioannou, D. Katsianis, and D. Varoutas, "Comparative techno-economic evaluation of LTE fixed wireless access, FTTdp G.fast and FTTC VDSL network deployment for providing $30 \mathrm{Mbps}$ broadband services in rural areas," Telecommunications Policy, vol. 44, no. 3, p. 101875, 2020, doi: 10.1016/j.telpol.2019.101875.

[20] A. Mousazadeh, M. Kafaee, and M. Ashraf, "Ranking of commercial photodiodes in radiation detection using multiple-attribute decision making approach," Nuclear Instruments and Methods in Physics Research, Section A: Accelerators, Spectrometers, Detectors and Associated Equipment, vol. 987, p. 164839, 2021, doi: 10.1016/j.nima.2020.164839.

[21] R. Fahlepi, "Decision Support Systems Employee Discipline Identification Using The Simple Multi Attribute Rating Technique (SMART) Method," Journal of Applied Engineering and Technological Science (JAETS), vol. 1, no. 2, pp. 103-112, 2020, doi: 10.37385/jaets.v1i2.67.

[22] G. M. Zanghelini, E. Cherubini, and S. R. Soares, "How Multi-Criteria Decision Analysis (MCDA) is aiding Life Cycle Assessment (LCA) in results interpretation," Journal of Cleaner Production, vol. 172, pp. 609-622, 2018, doi: 10.1016/j.jclepro.2017.10.230.

[23] B. Németh et al., "Comparison of weighting methods used in multicriteria decision analysis frameworks in healthcare with focus on low-and middle-income countries," Journal of Comparative Effectiveness Research, vol. 8, no. 4, pp. 195-204, 2019, doi: 10.2217/cer-2018-0102.

[24] C. Y. Wang and S. M. Chen, "An improved multiattribute decision making method based on new score function of interval-valued intuitionistic fuzzy values and linear programming methodology," Information Sciences, vol. 411, pp. 176-184, 2017, doi: 10.1016/j.ins.2017.05.022.

[25] Statistics of Semarang Municipality, Semarang municipalty in figures 2021. Semarang: Statistics of Semarang Municipality, 2021.

\section{BIOGRAPHIES OF AUTHORS}

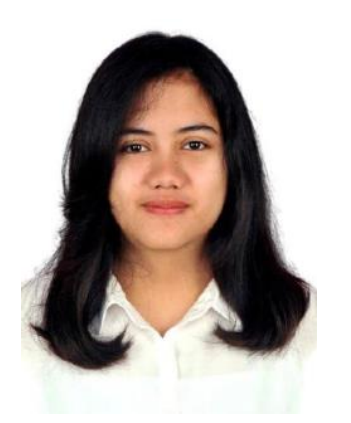

Putri Angelia (D) 8d SC P is an active student at Telkom University and is currently taking her final semester at master's education program at the faculty of electrical engineering with a major in regulation and management of telecommunication. She can be contacted at email: ptriangelia@student.telkomuniversity.ac.id.

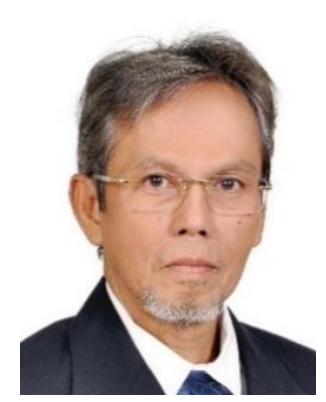

Prof. Dr. Rendy Munadi (D) SC SC has been a lecturer at the Faculty of Electrical Engineering at Telkom University (D/H STT Telkom) Bandung Indonesia since 1993. The field of research that is being carried out is the manufacture of a hemoglobin measuring device by utilizing the Internet of Things (IoT) based machine learning method, partner: Hasan Sadikin Hospital. Experience serving in universities since 1998 is as Head of Academic Administration (formerly STT Telkom) and Head of Telecommunication Engineering Study Program in 2005-2006. Served as Vice Chancellor for Academic Affairs in 2006-2010. Since 2018 he has served as an Assessor for FTE lecturer certification. Currently, he is a senior lecturer in the Network Cyber Management (NCM) expertise group. He can be contacted at email: rendymunadi@telkomuniversity.ac.id.

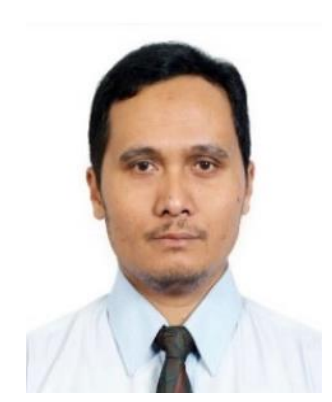

Dr. Nachwan Mufti Adriansyah, S.T., M.T. (D) 8 SC $\mathrm{P}$ is a lecturer at Telkom University. The material taught is about wireless communication, antenna propagation, radio engineering, telecommunication electromagnetics. Some of his researches are Channel Model for Indonesia 5G Networks, energy-efficient resources allocations for wireless communication systems, and other research. he also serves as Chairman of the KK Telecommunication Transmission. $\mathrm{He}$ can be contacted at email: nachwanma@telkomuniversity.ac.id 